\title{
XXXIX. On the question "Whether music is necessary to the orator,-to what extent, and how most readily attainable?
}

\section{Henry Upington Esq.}

To cite this article: Henry Upington Esq. (1818) XXXIX. On the question "Whether music is necessary to the orator,-to what extent, and how most readily attainable? , Philosophical Magazine Series 1, 52:246, 241-250, DOI: 10.1080/14786441808652043

To link to this article: http://dx.doi.org/10.1080/14786441808652043

曲 Published online: 23 Jul 2009.

Submit your article to this journal $₫$

Џll Article views: 2

Q View related articles $₫$ 


\title{
[241]
}

XXXIX. On the Question "Whether Music is necessary to the Orator, - to what Extent, and how most readily attainable?" By Henry Upington, Esq.

\author{
[Continued from p. 168.]
}

\section{To Mr. Tilloch.}

Y Blair's Hill, Cork, Sept. 16, 1818. Sin, - Y ou will no doubt perceive by the general tenor of my papers, but more especially by the tenor of my last, that I have aimed at little more than a comprehensive outline of my subject; and have therefore left to the good sense and discernment of my readers the supplying of several deficiencies which my disinclination for detail has unavoidably occasioned. Thus for example, in place of chiefly ascribing to the successively descending intervals with which our music abounds-the propensity of our public readers and orators to sink inaudibly through the scale at the termination of thẹir periods; 1 might also have adduced the wideness of interval, extent of scale, and usually inappropriate modulation when applied to speech, with which our songs and other musical productions so frequently conclude. In speaking too of the rhetorical cadence, 1 might have added that in several cases (especially when not preceded by a pause) this cadence is less distinctively marked than in others. I might also have qualified my assertion that " the ultimate falling syllables of an ancient period could never have exceeded two,"-by stating the probable exception in the Roman language, of a terminating monosyllable when preceded by a word of three or more syllables whose accent is seated on the antepenult : but, as 1 have already said, these and several other matters of detail have been intentionally left to the good sense and discernment of the reader.

To proceed then with my inquiry. A taste manifestly vicious in the extreme having for some time publicly appeared among the propagators of novelty in this kingdom, who in addition to the hideous extension of certain syllables, and the inarticulate crowding of others-would fain violate all the chasteness of language by the introduction of a periodical thump, the necessary consequence of executing any passige by the beat of time, conformably to our present mode of barring * ; my attention was, if possible, more carefully directed to the analysis of this than of any other topic. Not satisfied therefore with the coinciding opi-

nion

* The introducers of this barring system are the real or pretended admirers of "ProsodiuRationulis," whose anti-oratorical author, Joslua Steele, would extend our ordinary speaking scale to an octave and a half; and the duration of our syllables to the monstrous ratio of eight to one-while,

Vol.52. No. 246. Oct. 1818.

erell 
nion of my associate, I solicited the conjoint operation and opinion of several amateurs and professional musicians; by all of whom the following observations were unhesitatingly made.

\section{Examination of The Speaker continued. OF TIME.}

Observation 1st.-Alterations of the general movement were almost perpetual, every perceptible change of emotion producing, though even in the same clause, a corresponding ac celeration or retardation of delivery; while even in the most regular clause, no appreciable $b a r$ whatever, with the exception of an occasional approximation to our $\frac{2}{4}$ or $\frac{3}{8}$, could be said in any way to exist. Nevertheless, a triplet similar to that in "God save the King" did now and then attract our attention.

Olservation 2d.-Combinations more or less independent of our usual barring arrangement--and whose effect was at times peculiarly expressive-were continually perceived. But on these combinations we considered ourselves too inexperienced to report.

Olservation 3d.-Emphatical words, the vowel of whose emphatic syllable was long by nature [this term is used for perspicuity], were rather frequentiy marked by a moderate extension of those vowels; while in the case of short vowels, similarly circumstanced, scarcely any extension of these, at any time took place: nevertheless, in both instances a certain extension of prolongable consonants [not mutes] was occasionally obvious.

\section{Remarks on the preceding Olservations.}

The more attentively we consider the present barring system in its application to speech, the more numerous are the objections to its adoption. Besides that periodical thump which all time-

even in recitative, Handel is satisfied will four to one, and for the most jart with half this ratio. Let us take the rery first example which occurs in Steele's book, as a specimen of his taste, and conception of rhythmus.

In executing this passage let the experimenter take care that he not only beats the time, but allots the assigned duration to every individual syllable.]

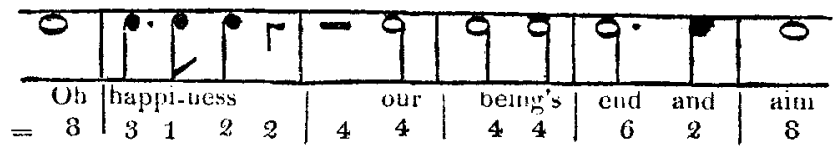

Casar's remark on the sing-song speaker may be justly applied to $\mathrm{Mr}$. Stcele: If this be singing, it is singing very badly. Some trifling ballad may possibly present one or two accidental lines to which, if expression be. not required, this time-beating process may somewhat closely be applied; -but who wuld coret the execution at so grcat a sacrifice? 
beating by forte must inevitably produce; - besides that horrific extension and inarticulate contriction of syllablesso inappropriate to oratory, which must consequently follow; - besides the impossibility, under regular time, of expressing our emotions by the immediate transitions from quick to slow and from slow to quick, to which we are instinctively prompted by those emotions*; besides these and many other objections which may be urged with regard to speech-is not the musician himself aware, that in proportion as he mechanically adheres to the exact execution of his musical time, even in song-in that proportion must he necessarily fall short of the admirable expression which distinguishes the celebrated solo singer from the grosser performer?

In recitative (the design of which is the imitation of speech), how much more the latitude! The performer must be heard; and whenever superior energy and expression are intended, he must conform in a striking degree to the irregular dimensions of our syllables, articulating, with requisite length, a considerable number, which the composer, for the preservation of imaginary time, has represented as very short; and shortening a number of those, especially the particles, which the composer may have represented too longt. The performer must also, on several occasions, extend for the sake of expression certain notes to which too limited duration had been assigned; and he must consequently shorten others. He must likewise constantly surpass his bars by syncopation: he must considerably derange that order of emphasis which the habitual character of our song prescribes: he must constantly pause where the sense requires, and disregard imaginary rests : in fine-to excel in recitative, he must unlearn, and with no small share of difficulty, all his previously contracted time-beating habits, adopting every method which art or nature may suggest, for the annihilation of his bars, and the attainment of more appropriate expression.

Against all these objections the advocates of barring will plead, and apparently with reason, the necessity of some certain basis for the establishment of regular proportion, from which the performer may afterwards more or less depart, as fancy regulated by general usage shall invite him. Now with these advocates I should probably agree as to the utility of barring, [not in their way by constantly commencing forte, ] were recitative not speech the uitimate object: but with regard to speech, whose latitude

* The ancients, whose taste in every thing that related to oratory was conspicuous, were particularly attentive to these transitions. Quintilian, in the $3 d$ chap. of the xith book of his Institutes, points them out to the orator as indispensably connected with expression.

+ Handel himself, in that superior passage which I have so often quoted, has marked equally with a semiquaver the words a, the, $I$, plung'd, blow. 
compared with recitative is undoubtedly greater than that of recitative compared with song, is there not a more simple and less objectionable method of cultivating proportion, by which the speaker shall neither misspend his valuable hours in learning the mechanical operation of beating our various species of time; nor acquire, in the remotest degree, any habit that shall endanger his delivery and cost him much subsequent trouble to remove?

To this simple method our attention will speedily be directed. But although it were ever so necessary, and even practicalle, for the orator to improve himself by speaking in barred productionswhere, as I already observed, is the master capable of composing and teaching them? In what species of time, $\frac{2}{2} \frac{3}{8}, \frac{6}{8}$, or even $\frac{5}{8}$, separately or mixed, shall they be written? And although this question which appears unanswerable should he solved-shall the orator even then sacrifice his own, and in all probability superior ideas of beauty, to the ultimate setting of a Joshua Steele?

The total impracticalility, however, of executing speech, even with tolerable accuracy, in any species of musical time, is in my opinion self-evident. Nothing for the ascertainment of this fact has on my part, or on that of my Associate and other musical assistants, been left undone. Various passages were selected, and all equally failed. At length we confined ourselves to that passage which Joshua Steele had intentionally chosen in the outset of his work as the foundation of his theory, "Oh happiness, \&c." and which I have already given as set by that fanciful gentleman. This passage was separately taken up by each individual, and set in that form which in his opinion was most analogous to the delivery of our chastest speakers, and at the same time consonant, as much as possible, with musical usage:-all these settings were compared; and after mature discussion, the following was preferred:

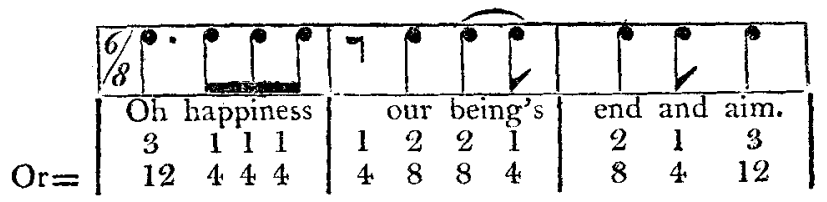

The exact musical execution of this piece now followed: the time was regularly beat, and the relative proportion of every note observed as systematically as in concert: but the result was intolerable:-it was any thing but speech.

A reader of the superior order attended our consultation. He slowly recited the passage. Some trifling defects were observed, especially in the execution of the last word, which by over-extension produced too much the effect of an independent line without 
without reference to the succeeding. These defects were remedied : the passage was practised, and finally delivered, as well as the human ear could estimate so irregular a combination, in the following proportions, the rhythmical divisions or bars being exactly ascertained by viewing an adjusted pendulum which vibrated seventy-two times in a minute. The recital of the six divisions occupied precisely five seconds of time, or six vibrations.

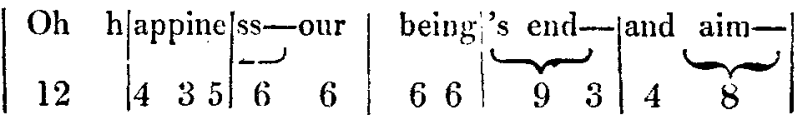

This unavoidable irregularity of proportion in syllables, -expecially the short ones, which consistently with the character of language can neither be contracted nor extended, but in a very limited degree-was equally ackuowledged by the ancients; Dionysius of Halicarnassus having supplied us in this respect with an interesting document unknown to the generality of our best informed. This intelligent critic, in the xvth section of bis celebrated work on language, has the following passage; which proves to our satisfaction that the Greeks themselves, who possessed the most regular language ever formed by man, never entertained the chimerical notion of reciting even their poetry in any thing like accurate time or quantity. This passage being rather long, I shall give it a summary translation.

"It must be confessed," says Dionysius, " that the syllable is short which consists of a short vowel, suppose o in ofós. Prefix to this the semivowel $\dot{\rho}$ as pónos, and the syllable remains short-not lowever in the same manner, as it will have a certain minute addition of time more than the former. Prefix again the mute $\tau$, as $\tau$ gón $^{\prime}$ s $_{\text {: }}$ this syllable will then be greater than the former syllables, and yet it remains short. Prefix a third letter, as $\sigma \tau \varrho o ́ \phi 05:$ and by these three audible additions it becomes still longer. The same with our long syllables: $\eta$ if increased by the addition of four letters, as in $\sigma \pi \lambda \dot{r} y$, wonld certainly be rendered greater than when it consisted of the single letter. It is suffcient to say, that a short syllable differs from a short, and a long. syllable from a long one; and that every short has not the same power, neither has every long, whether in prose or in poetry."

Such was the Grecian usage-such the Roman-and such must continue the necessary usage of this and of every other country.

To what purpose then, say our modern disputants, have all the regulations of imaginary quantity been established by the ancients? and have not these regulations contributed to larbarize both languages, particularly the Roman? These are the general questions of uninformed critics, and to these I shall parQ 3 ticularly 
ticularly reply (if "reply I may call it), by asking them a few questions in my turn.

1st. Have you ever known an individual who gave himself the trouble of reading either language by the outline of quantity? If not-how can you decide on the utility or inutility of those bulwarks against innovation which Grecian taste and judgement so industriously erected?

$2 \mathrm{~d}$. Are you aware that long quantity does not consist in the enunciation of what is called a long vowel, but in the appropriate extension of syllables, which by the ageney of vowels and prolongable consonants we are enabled to accomplish ?

3d. Are you aware that syllables called by our countrymen long, - as the last syllable in remove, - can with a little practice be uttered as quickly as the last syllable in remit?

4th. Can you readily pronounce with considerable extension, the second syllable of sábaoth* (emphasis or accent on the first) - or the last syllable of your own word dedicate, without destroying the chaste Englis/ character of these words? If. notlearn, for I have heard it frequently done.

5th. Do you perceive, by the tendency of my two last questions, that ancient Iambics like dócēs may and can be read in quantity, preserving the emphasis or accent on the first syllablet?

6th. When you reflect on Quintilian's observation, 一 that in certain cases it required some delicacy of ear to distinguish whether

* Mr. Walker in his Classical Pronouncing Dictionary has this extraordinary note on the word stbaoth. "This word should not be confounded in its pronunciation with sabbalh. Sábaoth ought to be heard in three syllables, by keeping the $a$ and $g$ separate and distimct, which it must he confessed is not easy to do." Not easy ! wretched must be the babits of that speaker who tinds it difficult.

$t$ The character of this Iambus, when commanded, is wonderfully martial. I have heard the English word cóhorts so uttered-first syllable short; second verylong - without any deviation from the usual vowel sounds : bat I considered it very extraordinary that when the speaker thought proper, he could render the second syllable incomparably louder than the first, without altering what an Finglish ear would denominate the stress or accent. This phænomenon being closely investigated, the deception was discovered: the second syllable was actually weaker th:u the first at its commencement; but having terminated in a crescendo, thus:

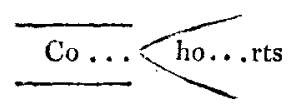

every ear was satisfied with the imaginary execution of the accent.

$B_{y}$ reversing the character, it became incredibly soft-as thus:

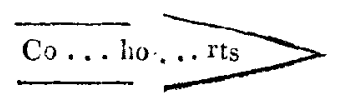

It was more than Italian. 
a long syllable were really so delivered-are you not compelled to infer, that, agreeably to ancient practice, the naturally long unemphatic vowels were seldom extended equally with the long emphatic ones?

$7 \mathrm{th}$. Have you learned from the 14 th section of Dionysius of Halicarnassus, that the short vowels of the ancients were not, like our short ones, incapable of prolongation without constituting a novel sound? - but that the narrowness or effeminacy

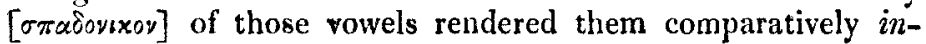
eligille for extension?

8th. Have you ever been informed that a syllable naturally short, as the first in lodkin, may be considered as extended by the addition of that trifling interruption which is perceptible between the $d$ and $k$; in the ratio of about 4 to $3:$ or in other words, that this interruption or rest may, in the case of syllables equally short with bod, be accounted equivalent to the one-third of every such syllable? - and do you not imagine that on several occasions a delicate extension of the vowel itself *, as well as of prolongable consonants, did likewise take place, for the additional assistance of the rhythmus?

9 th. Do you inagine that in reading the Classics, or even in speaking your own language, you ever iterate (in the same word) an immediately preceding consonant, as the $d$ in goddess? And yet that it can be sounded, you must acknowledge by attending to your own pronunciation of the two d's in bad day, good day, \&c. You may possibly allege that such mode of pronunciationrequiring as it does the distinct delivery of every written character, and which would clearly and strongly articulate even the second syllable in imperfection or tolerate-nust have rendered the Classical languages much slower than our own. I grant it. But will you insist that our speaking more slowly and intelligibly than we do, could render us more imperfect as orators, or lessen our dignity as a nation?

* In reading the ancient languages, I do not argue for any unnecessary innovation in our present manner of sounding all kinds of vowels, when metre is not in question. It is judicious, in my opinion, to conform in every possible manner to the usage of our native tongue; but certainly, if an ancient Greek had proposed the abolition of his noblest vowel á $\lambda \phi a$, and the substitution of our narrow $e e$ for his open $\tilde{n}+x$, I should compare bim, and deservedly, to a musician who having in his possession five different bells, should demolish the noblest, and choke the second for the improvement of lis melody. But with respect to our rhythmus; why not substitute the long vowel sound for that of the short in all position cases where the ear shall actually require such substitution? And would not the cousequent melody which such reading wonld produce, materially influence our national elocution? Thus would the ancient Hexameter be restored to its original sublimity, and the metre of Horace, while sufficiently rough, be no longer stigmatized by the illiterate as the jargon of a Hottentot. 
10th. In reading both the Greek and Latin languages, (but especially the latter, ) do you regularly attend to the due extension; or in your own phraseology, do you give the long sound to all those vowels which are by nature long, regardless of their nominal length by position? And are you certain that the Grecian language with respect to its emphatic syllables (especially in its poetry, to which almost every license was extended) is regulated like the Roman *?

These are the great outlines of time or quantity (as well as forte), without the understanding and observance of which it is in my mind an impossibility to form an adequate opinion of the prosody of the ancient languages; and consequently of the effects of the various combinations which with most advantage may be introduced into our own. The idea of barring in the modern way, must however, to all appearance, be set down not only as destructive to oratorical delivery; but, in addition, as necessarily excluding (even by the confession of Rousseau himself) every species of combination, except that isolated one $t$, which, for the facility of keeping time in concert, such limited system would impose. Even in their music, the ancient latitude in the collocation of long and short was much greater than ours: and hence, for want of experience, the almost insuperable difficulty, with modern musicians, of executing with precision certain fragments which accident has preserved ; such, for example, as that portion of a Pindaric ode with which we have been favoured in the Musical Dickionary of the before-mentioned writer.

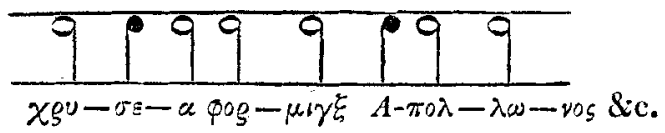

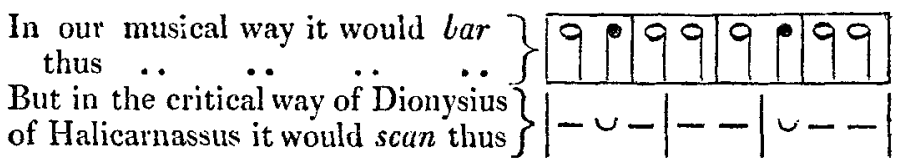

* Our present covecption of the Roman stress or accent is in my opinion invariably correct: however, in neirher Greek nor Roman language does it appear in general so decisively murkea as in our own.

1. "Cette inaniere d'exprimer le tems ou la mesure des notes changea entièrement durant le cours du demier siècle. Dès qu'on eut pris l'babitude de renfermer chaque mesure entre deux harres, it fallut nécessairement. proscrire toutes les especes de notes qui renfermoient plusieurs mesures." See Rousseau's Musical Dictionary, article Mesure.

The opinion of Vossius too, upon this subject, has been respectfully quoted by Rousseat in the following words: "Il dit, qu'un rhythme détuché comme le nôtre qui ne représente aucune image des choses, ne peut avoir aucun effet; et que les anciens nombres poćtiques n'avoient ćé inventés que pour cette fin que nous nćgligenns."

constituting 
constituting by this judicious method, a Cretic, a Spondee, and a Bacchic,- of whose metrical characters a more definite notion can be formed than of those of the mixed Trochee or Iambus, which immediately lose themselves in combination.

When the Greek and Latin languages shall be rightly cultivated, and delivered as they ought; then, and not till then, may we presume to analyse the genuine character of those measures in which every poet and orator of notoriety excelled : and therefore I shall postpone, if not absolutely avoid, the intricate discussion, from the conscious difficulty of conveying my ideas in perspicuous language even when accompanied by oral exemplification. This letter on Time or Quantity must conclude then by an attempt, (and I hope not altogether a fruitless one,) finally to investigate,-on what rhythmical principle, independently of feet, the well-executed recitation of our best poetry depends.

Adhering most strictly, in the pursuit of this question, to my original design, I rejected as usual all speculative notions, and resorted to experiment. The reciter by whom "Oh happiness" was spoken, indulged my curiosity; and two intelligent musicians, together with my assocrate, lent me the assistance of their eyes and ears-their eves to ascertain the boundaries by the movement of a pendulum (beating time with the hand being too clumsy a criterion); and ears for the subsequent measurement, in some tolerable manner, of the relative proportions.

The poet was next sought for, and MiLToN obtained the general approbation. Half a dozen sufficiently regular lines of the "Paradise Lost" (the more oratorical* ones though excelling the others in sublimity having baffled our attempts) were chosen, practised and repractised with remarkable distinctness, until every ear was pleased. Of these lines an adequate conception may be formed by the terminating one of the exordium; and this for the gratification of the reader I shall transcribe exactly as it was spoken.

[In the following experiment I have not particularly designated the position $\uparrow$ syllables, such minute accuracy being too perplexing.]

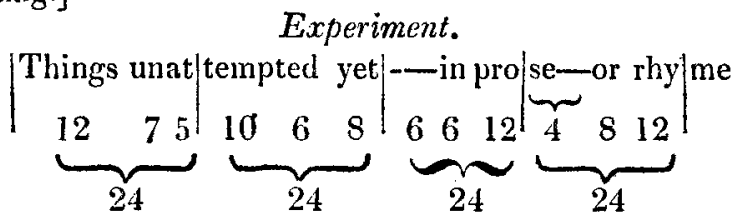

* "And chiefly thou Oh! spirit" down to " mad'st it pregnant" were amoug this number.

$\dagger \AA$ position syllable too quickly uttered cannot be considered long. The dic in dictio, or even the trac in tructus, may, if the speaker choose, be equalized with the shortest syllables in the Latin language. 
Let us reduce this passage, as nearly as we can, to some musical standard; and the mixed characters of time will be more conspicuous. Suppose thus:

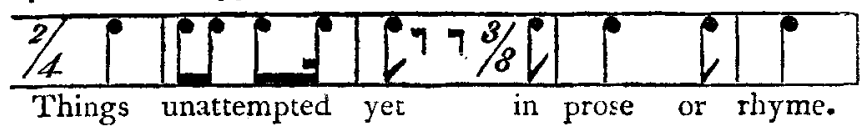

Or even thus:

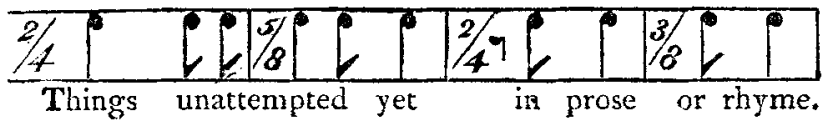

Does not this experiment throw a considerable light upon our subject? Here may be discovered that the rhythm of language is governed as it should be, by time and not by noise: that considerable deviations from all rhythmical regularity are necessary to the sublime: that barring in the ordinary way, by perpetually commencing forte, even in song, but especially in recitative, is unscientific* in the extreme: that speech, without torturing the character of words, has its own proportions, employs its syncopations, and commands its crescendo as well as diminuendo partitions: that silence, according to ancient conception as well as modern experience, must necessarily constitute a portion of the rhythmical whole: and finally, that time of the common, triple, and even quintuple character is so frequently and peculiarly blended, that no musical annotation can represent it.

What argument can our speech-barring advocates oppose to such undeniable facts? Of these gentlemen, then, I shall for this time take my leave, by obtruding upon their notice an established maxim of my Associate, who was literally born a musician; that as the most grovelling of all musical performers is the country fiddler who employs the agency of force to designate his bars-so the most contemptible of all reciters is he who marks the boundary of his measures by the instrumentality of accent.

[To be continued.]

* Slovenly and imperfect too in its result-a certain habitual crowding of the several integral parts within the given boundary, and not the relative proportions of those integral parts themselves, being the principal requisite for the preservation of wodern time. In proof of this assertion, deprive any ordinary tune which the musician has not previously heard, of his perpendicular guides called bars-and so far from playing such tune in concert, he will be incapable of playing it at all. Roussisu has given us, under the article Barres, a curious anecdote confirmatory of my assertion: "Auparavant la musique étoit simple : cependant j'ai vu nos meilleurs tnusiciens embarrassés à bien exécuter l'ancienne musique d'Orlande et de Claudin. Ils se perdoient dans la mesure, faute des barres, et ne suivoient qu'aver peine des parties chantées autrefois couramment par les musiciens de Henri III. et de Charles IX." 